\title{
Effect of Different Levels of arka microbial consortium on seed germination and survival rate in Brinjal cv. Dommeru Local
}

\author{
K. Venkata Subbaiah ${ }^{1 *}$, R.V.S.K. Reddy ${ }^{1}$, G. Shali Raju ${ }^{2}$, E. Karunasree ${ }^{3}$, V. Sekhar ${ }^{3}$ \\ T. Vijaya Nirmala ${ }^{4}$, A. Devivaraprasad Reddy ${ }^{5}$ and V.Deepthi ${ }^{6}$ \\ ${ }^{1}$ Horticulture, Dr. YSRHU, Venkataramannagudem, ${ }^{2}$ Entomology, ${ }^{3}$ Statistics, ${ }^{4}$ Veternary, \\ ${ }^{5}$ Fisheries Science, ${ }^{6}$ Extension, K.V.K. Venkataramannagudem, India \\ *Corresponding author
}

\section{A B S T R A C T}

\begin{tabular}{|l|}
\hline Ke y w o r d s \\
Arka microbial \\
consortium, Brinjal, \\
Germination (\%), \\
Survival rate (\%) \\
\hline Article Info \\
\hline $\begin{array}{l}\text { Accepted: } \\
\text { 20 May 2018 } \\
\text { Available Online: } \\
\text { 10 June } 2018\end{array}$ \\
\hline
\end{tabular}

A study was conducted to study the effect of different levels of arka microbial consortium on seed germination, seedling growth parameters and survival percentage in Brinjal cv. Dommeru local at Krishi Vigyan Kendra, Dr. Y.S.R. Horticultural University, West Godavari district, Andhra Pradesh, India. Arka microbial consortiums with different levels were tried. The experiment was laid out in Completely Randomized Design, with seven treatments and replicated thrice. Results showed that $6 \mathrm{~g}$ Arka microbial consortium per $1 \mathrm{~kg}$ Coco peat gave highest germination percentage $(88.43 \%)$, least germination period (6days), more seed vigour $(89.30 \%)$, more seedling height $(13.59 \mathrm{~cm})$, more number of leaves per seedling (6.47), more Leaf area $(47.50$ sq.cm), more root length $(6.38 \mathrm{~cm})$, more Seedling fresh weight $(3.40 \mathrm{~g})$, dry weight $(0.64 \mathrm{~g})$, more Survival rate $(97.45)$ and less days to transplant (26 days). The least values were recorded in control under west Godavari district of Andhra Pradesh conditions.

\section{Introduction}

Brinjal (Solanum melongena Linn.) is a popular vegetable crop in our India and belongs to the family Solanaceae. Plant is herbaceous, annual with erect or semispreading in habit. It also behaves like a perennial herb. It is quite high in nutritive value and can be well compared with tomato. Brinjal fruit contains high amount of carbohydrates $(6.4 \%)$, protein $(1.3 \%)$, fat $(0.3 \%)$, calcium $(0.02 \%)$, phosphorus $(0.02 \%)$, iron $(0.0013 \%)$ and other mineral contents. Apart from these, it also contains $\beta$-carotene
(34 $\mathrm{mg})$, riboflavin $(0.05 \mathrm{mg})$, thiamine $(0.05$ $\mathrm{mg})$, niacine $(0.5 \mathrm{mg})$ and ascorbic acid $(0.9$ $\mathrm{mg}$ ) per $100 \mathrm{~g}$ of fruit (Choudhary, 1976). Raising of brinjal seeds in nursery is essential thing to get quality and healthy seedlings, these established seedlings will yield quite early and fetch higher price in the market, hence these are economically profitable. In nurseries, seedlings are generally produced in protrays. Soil less mixtures such as cocopeat, perlite, vermicompost etc, is usually used for commercial seedling production. There is a great demand to produce quality and healthy seedlings, which are ability to withstanding 
adverse biotic and abiotic stresses after transplanting with improved mineral nutrient uptake (Nzanza et al., 2011). A pre-sowing inoculation of planting medium with the consortia of beneficial microorganisms is an innovative approach for production of quality and healthy seedlings in horticultural production. Arka Microbial Consortium is a carrier based product which contains $\mathrm{N}$-fixing, $\mathrm{P} \& \mathrm{Zn}$ solubilizing and plant growthpromoting microbes as a single formulation. It will reduce the cost of chemical fertilizer and finally reduces cost of cultivation and also helps in sustainable vegetable production. Dommeru local is a local variety which was extensively grown in west Godavari district of Andhra Pradesh. It had some problems like low germination percentage, less vigour and least survival percentage after transplantin to main field Hence the present study was conducted to evaluate the effect of different levels of Arka Microbial Consortium on seed germination and survival rate in Brinjal cv. Dommeru local under west Godavari district of Andhra Pradesh.

\section{Materials and Methods}

An experiment was conducted at Krishi vigyan Kendra model nursery, Dr. Y. S. R. Horticultural university, Venkataramannagudem, West Godavari district (India) during rabi season, 2017-18. The nursery was raised under 30 per cent shade net. The experiment was laid out in Completely Randomized Design with three replications. The media comprised of coco peat, vermicompost and Arka microbial consortium with seven treatment combinations and replicated thrice. The healthy Dommeru local brinjal seed was collected from progressive farmer and sown in pro trays as per the treatment combinations. Three pro trays were selected randomly for recording observations in each treatment and data were recorded on germination percentage, germination period, seed vigour, survival and other growth parameters at 30 days after seed sown.

Germination percentage was calculated by number of germinated seeds divided by the total number of seeds sown in pro trays and multiplied by 100 . Germination period was calculated as the difference between initial and final emergence (number of days). Seed vigour was calculated by dividing total number of healthy seedling by total number of seedlings, and multiplied by 100 . Counting of number of leaves was done at the end of the experiment. Plant height was measured from the base of the seedling to highest tip of the plant. Leaf area was calculated by tracing the leaves on a graph paper. Survival \% (7 days after transplanting in the main field) was recorded using the following formula;

Total number of surviving

transplanted seedlings

Survival $\%=\frac{\begin{array}{c}\text { Total number of } \\ \text { transplanted seedlings }\end{array}}{} \times 100$

\section{Results and Discussion}

Brinjal seedling parameters as influenced by different concentrations of arka microbial consortium (AMC) are presented in Table 1. Among the different concentrations, the highest germination percentage was found in $6 \mathrm{~g}$ AMC per $1 \mathrm{~kg}$ Coco peat (T6) $(88.43 \%)$ followed by in $5 \mathrm{~g}$ AMC per $1 \mathrm{~kg}$ Coco peat (T5) $(78.69 \%)$, T4 (73.64\%) and lowest germination percentage was noticed in control (T7) (56.28). Less germination period was found with $6 \mathrm{~g}$ AMC per $1 \mathrm{~kg}$ Cocopeat (T6) (6.00 days) followed by in $5 \mathrm{~g}$ AMC per $1 \mathrm{~kg}$ Cocopeat (T5) (7.00 days) and with 3g AMC per $1 \mathrm{~kg}$ Coco peat (T3) (7.00 days) and the highest germination period was found with control (T7) (10 days). The highest seed vigour was noticed with T6 $(89.30 \%)$ which was statistically at par with T5 $(88.81 \%)$, T4 $(88.15 \%)$ and the lowest seed vigour was found in control (T7) (77.51\%). Maximum seedling height was recorded in T6 $(13.59 \mathrm{~cm})$ 
and it was statistically at par with T5 (13.27 $\mathrm{cm}$ ) and the minimum seedling height was noticed with $1 \mathrm{~g}$ AMC per $1 \mathrm{~kg}$ Coco peat (T1) $(9.60 \mathrm{~cm})$. The more number of leaves per seedling was recorded in T6 (6.47) which was statistically at par with $4 \mathrm{~g}$ AMC per $1 \mathrm{~kg}$ Coco peat (T4) (6.00) and the less number of leaves were noticed in $3 \mathrm{~g}$ AMC per $1 \mathrm{~kg}$ Coco peat (T3) (4.63), where as in case of leaf area the highest leaf area was found in T6 (47.50 Sq.cm) which was on par with T4 (45.83 Sq.cm) and lowest leaf area was noticed in control (T7) (26.83 Sq.cm). The more root length was recorded in treatment T6 $(6.38 \mathrm{~cm})$ which was statistically at par with T5 (6.18 $\mathrm{cm}), \mathrm{T} 3(6.10 \mathrm{~cm}), \mathrm{T} 4(5.97 \mathrm{~cm}), \mathrm{T} 2(5.83$ $\mathrm{cm}), \mathrm{T} 1(5.64 \mathrm{~cm})$ and the less root length was found with treatment $\mathrm{T} 7(4.16 \mathrm{~cm})$. The more seedling fresh and dry weight was recorded in T6 (3.40 g) (0.64 g) respectively but in case of less seedling fresh weight was recorded in T7 $(2.12 \mathrm{~g})$, T3 $(2.12 \mathrm{~g})$, seedling dry weight noticed in T5 and T3 $(0.38 \mathrm{~g})$. The least days to transplanting to main field was recorded in T6 (26 days) which was statistically at par with T5 (28.33 days). The more number of days to transplanting was noticed in control (T7) (34 days). This indicates that the arka microbial consortium reduces the nursery period by one week. With respect to survival percentage the more survival percentage was recorded in $\mathrm{T}_{6}(97.45 \%)$ which was statistically at par with T5 (97.25), T4 $(96.35 \%)$ and less survival percentage was recorded in control $(78.60 \%)$. In all treatments, highest germination percentage $(88.43 \%)$, least germination period (6days), more seed vigour $(89.30 \%)$, more seedling height $(13.59 \mathrm{~cm})$, more number of leaves per seedling (6.47), more Leaf area (47.50 sq.cm), more root length $(6.38 \mathrm{~cm})$, more Seedling fresh weight $(3.40 \mathrm{~g})$, dry weight $(0.64 \mathrm{~g})$, more Survival rate (97.45) (Fig 2) and less days to transplant (26 days) recorded in $6 \mathrm{~g}$ AMC per $1 \mathrm{~kg}$ Cocopeat (T6).

Table.1 Germination, vigour other seedling parameters as influenced by Arka microbial consortium (AMC) on Brinjal cv. Dommeru local

\begin{tabular}{|c|c|c|c|c|c|c|c|c|c|c|c|}
\hline है & 昰 & 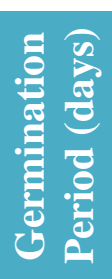 & 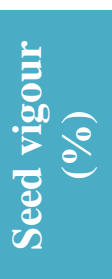 & 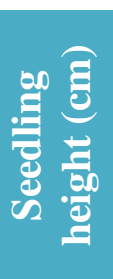 & 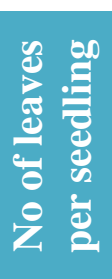 & 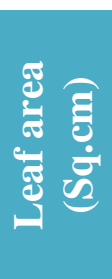 & 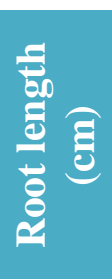 & 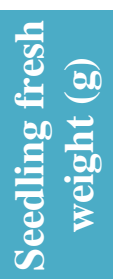 & 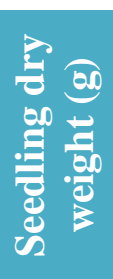 & 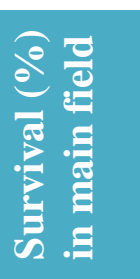 & $\begin{array}{l}\text { Days } \\
\text { taken } \\
\text { for } \\
\text { transpla } \\
\text { nting }\end{array}$ \\
\hline $\mathrm{T1}$ & 56.29 & 7.33 & 82.53 & 9.60 & 5.20 & 31.07 & 5.64 & 2.77 & 0.44 & 95.87 & 32.67 \\
\hline $\mathrm{T} 2$ & 64.73 & 8.00 & 85.56 & 11.56 & 4.93 & 33.83 & 5.83 & 2.30 & 0.53 & 92.03 & 32.67 \\
\hline T3 & 61.00 & 7.00 & 87.94 & 10.37 & 4.63 & 34.00 & 6.10 & 2.12 & 0.38 & 95.78 & 30.00 \\
\hline $\mathrm{T} 4$ & 73.64 & 8.00 & 88.15 & 9.54 & 6.00 & 45.83 & 5.97 & 2.17 & 0.57 & 96.35 & 30.00 \\
\hline $\mathrm{T5}$ & 78.69 & 7.00 & 88.81 & 13.27 & 5.53 & 34.17 & 6.18 & 2.98 & 0.38 & 97.25 & 28.33 \\
\hline T6 & 88.43 & 6.00 & 89.30 & 13.59 & 6.47 & 47.50 & 6.38 & 3.40 & 0.64 & 97.45 & 26.00 \\
\hline $\mathrm{T7}$ & 56.28 & 10.00 & 77.51 & 11.30 & 5.80 & 26.83 & 4.16 & 2.12 & 0.48 & 78.60 & 34.00 \\
\hline $\operatorname{SEm}( \pm)$ & 0.58 & 0.25 & 0.40 & 0.16 & 0.21 & 0.80 & 0.26 & 0.08 & 0.06 & 1.23 & 0.87 \\
\hline $\begin{array}{c}\text { CD at } \\
5 \%\end{array}$ & 1.75 & 0.76 & 1.23 & 0.47 & 0.63 & 2.42 & 0.78 & 0.25 & 0.17 & 3.73 & 2.65 \\
\hline
\end{tabular}

T1- 1g AMC per $1 \mathrm{~kg}$ Cocopeat, T2-2g AMC per $1 \mathrm{~kg}$ Cocopeat, T3-3g AMC per $1 \mathrm{~kg}$ Cocopeat, T4-4g AMC per $1 \mathrm{~kg}$ Cocopeat, T5-5g AMC per $1 \mathrm{~kg}$ Cocopeat, T6-6g AMC per $1 \mathrm{~kg}$ Cocopeat, T7- Control. 


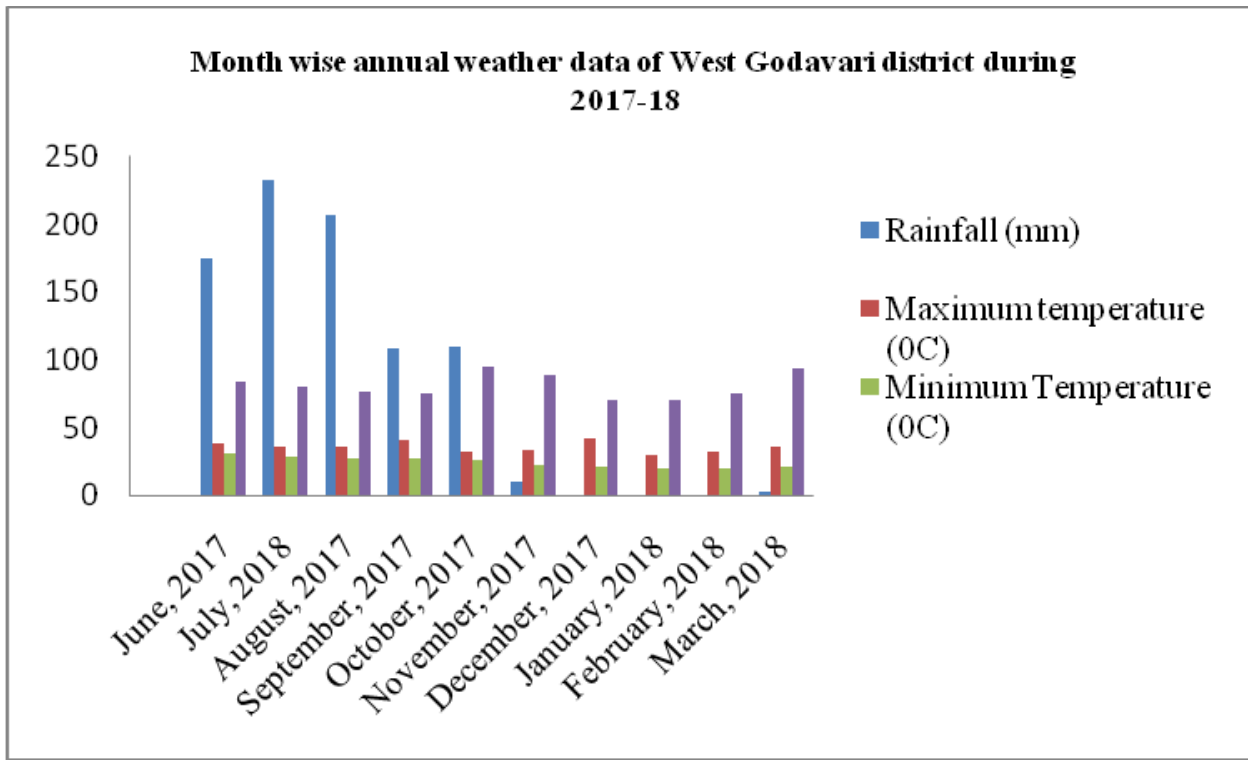

Fig 1: Month wise annual weather data of West Godavari district of Andhra Pradesh during 2017-18

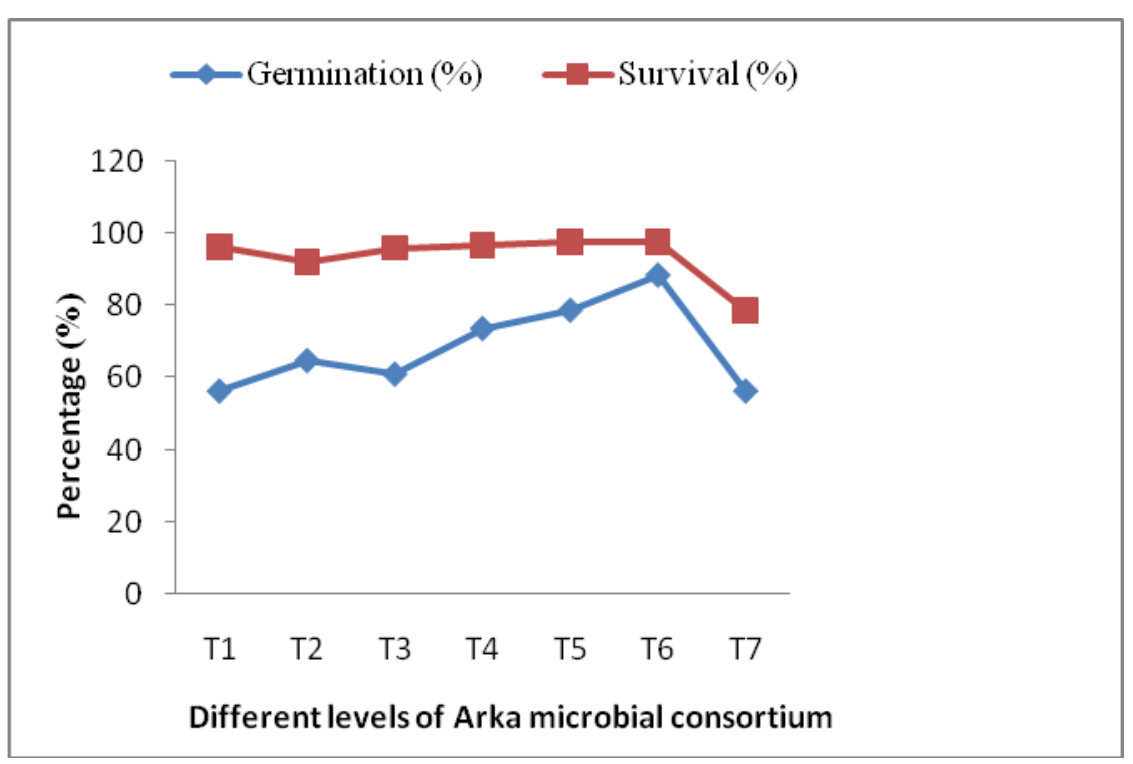

Fig 2: effect of different levels of arka microbial consortium on germination perentage and survival per centage 
This pointed out that the treatments without arka microbial consortium recorded less values for all the parameters and among the arka microbial consortium treatments, the values for all parameters were increased with increase in levels of arka microbial consortium. These results can be attributed to a reason that production of plant growth promoting substances by plant growthpromoting microbes which were known to cause enhanced cell division and root development higher nitrogen fixation by nitrogen fixing bacteria, phosphorous and zinc solubilization by phosphorous solubilizing bacterium and zinc solubilizing bacteriums respectively was responsible for early germination, healthy and quality seedlings. the present study was also supported by the findings of Sarvanan et al., (2012) in Casuarina equisetifolia seedlings, (Shenoy and Kalagudi, 2002) and Jayashree et al., 2016. From this study, we can be concluded that the arka microbial consortium comprises of different microbial strains which were perform different functions like early germination, Seedlings become ready for early transplantation by 5-7 days, increased seed vigour and high survival percentage in main field can be used to treat cocopeat @6g kg-1 to produce quality brinjal seedlings raised in protrays.

\section{References}

Choudhury, B. (1976). Vegetable. National Book Trust, New Delhi (INDIA).

Jayashree, C. and Jagadeesh, K.S. 2016, Nursery inoculation of the selected vegetable seedlings with a microbial consortium and its field performance in brinjal (Solanum melongena L.). M.Sc Thesis, Univ. Agric. Sci., Dharwad.

Nzanza, B., Diana, M. and Puffy, S. 2011. Tomato (Solanum lycopersicum L.) seedling growth and development as influenced by Trichoderma harzianum and arbuscular mycorrhizal fungi. African J. Microbiol. Res., 5(4): 425431.

Sarvanan, T.S., Rajendran, K. and Santhaguru, K. 2012. Selection of suitable bio-fertilizer for production of quality seedling of Casurina equisetifolia using decomposed coir pith compost in Root Trainers. Asian J. Exptl. Biol. Sci., 3(4): 752-761.

Shenoy, V.V. and Kalagudi, G.M. 2002. Plant host mediated enhancement of phosphorus use efficiency. In: Nation. Symp. on Mineral Phosphate solubilization- 2002 (A. R. Alagawadi et al., eds.), Univ. Agric. Sci., Dharward, pp. 11-12.

\section{How to cite this article:}

Venkata Subbaiah, K., R.V.S.K. Reddy, G. Shali Raju, E. Karunasree, V. Sekhar, T. Vijaya Nirmala, A. Devivaraprasad Reddy and Deepthi, V. 2018. Effect of Different Levels of arka microbial consortium on seed germination and survival rate in Brinjal cv. Dommeru Local. Int.J.Curr.Microbiol.App.Sci. 7(06): 2821-2825. doi: https://doi.org/10.20546/ijcmas.2018.706.331 